\title{
PENINGKATAN KEMAMPUAN MENULIS KARANGAN EKSPOSISI DENGAN MENGGUNAKAN STRATEGI PICTURE AND PICTURE SISWA KELAS VIII-6 SMP NEGERI 12 MAKASSAR
}

\begin{abstract}
Andi Nurmiati
ABSTRAK

Jenis penelitian ini adalah classroom action research (penelitian tindakan kelas). Penelitian ini bertujuan untuk mendeskripsikan peningkatan proses dan hasil pembelajaran menulis karangan eksposisi dengan menggunakan strategi picture and picture siswa kelas VIII-6 SMP Negeri 12 Makassar. Data penelitian ini adalah penilaian guru dan penilaian siswa dalam menilai kemampuan menulis karangan eksposisi pada proses pembelajaran dan hasil pembelajaran. Sumber data penelitian ini adalah guru bahasa Indonesia 1 orang dan siswa kelas VIII-6 yang berjumlah 26 orang. Teknik yang digunakan mengumpulkan data, yaitu: observasi, dokumentasi, dan penugasan. Data proses penelitian dianalisis dengan teknik deskriptif kualitatif sedangkan data hasil pembelajaran dianalisis dengan teknik deskriptif kuantitatif. Hasil penelitian menunjukkan bahwa pembelajaran menulis karangan eksposisi mengalami peningkatan, baik dalam proses pembelajaran maupun hasil pembelajaran. Proses pembelajaran menulis siklus I kurang memuaskan dan suasana kelas kurang kondusif. Guru belum melaksanakan kegiataan pembelajaraan secara maksimal, sehingga masih terdapat siswa yang sulit menuangkan ide atau gagasan dalam menulis karangan eksposisi. Proses pembelajaran siklus II lebih efektif dan memuaskan setelah dilakukan perbaikan terhadap masalah pada siklus I. Pada siklus II, guru melaksanakan kegiatan pembelajaran menulis dengan baik. Hal tersebut juga berpengaruh pada proses aktivitas siswa dalam pembelajaran. Pada siklus II siswa lebih antusias dan termotivasi mengikuti pembelajaran, saling bekerja sama dalam kelompok, serta tidak sulit ketika menuangkan ide atau gagasan dalam menulis karangan eksposisi. Nilai hasil pembelajaran menulis karangan eksposisi secara umum meningkat. Peningkatan itu terlihat dari nilai rata-rata siswa secara keseluruhan pada siklus I sebesar 66,03, sedangkan nilai pada siklus II sebesar 79,96 dengan persentase peningkatan $13,93 \%$. Semua aspek penilaian tergolong sangat kurang pada siklus I dan meningkat ke kategori baik pada siklus II.
\end{abstract}

\section{Kata Kunci: Eksposisi dan Picture and Picture}

This research was a classroom action research. This study aimed to describe the increase in process and outcomes of learning to write essays exposition by using strategic picture and picture - 6 eighth grade students of SMP Negeri 12 Makassar . The data of this study was the evaluation and assessment of teachers in assessing students' ability to write exposition essay on the learning process and learning 
outcomes . The data source of this study was 1 Indonesian teachers and students of class VIII - 6 , amounting to 26 people. The techniques used to collect the data, namely : observation, documentation, and assignments . The data were analyzed with the qualitative descriptive techniques while learning outcome data were analyzed with descriptive quantitative techniques. The results showed that learning to write essays exposition has increased, both in the learning process and learning outcomes. The process of learning to write the first cycle is less satisfying and less conducive classroom atmosphere. Second cycle, learning process more effective and satisfactory after the repair of the problem of cycle I. In the second cycle, the teacher was conducting learning to write well. It also affected the activity of students in the learning process . In the second cycle students were more enthusiastic and motivated to follow the learning, work together in groups, and it was not difficult when ideas or ideas in essay writing exposition. Value exposition essay writing learning outcomes in general increased. The increase was seen from the average value of students as a whole in the first cycle was 66.03 , while the value of the second cycle of 79.96 with a percentage increase of $13.93 \%$. All aspects of the assessment were relatively very less in the first cycle and increases to both categories in the second cycle

\section{Keywords : Exposition and Picture and Picture}




\section{Pendahuluan}

\section{Sebuah karangan eksposisi \\ dapat tersusun dengan berbagai \\ komponen sebagai syarat terbentuknya suatu karangan yang lengkap.}

Komponen yang dimaksud seperti isi, paragraf, penggunaan bahasa, keteraturan susunan dan urutan, pilihan kata, dan penggunaan ejaan dan tanda baca. Oleh karena itu, seseorang yang mampu menyusun karangan eksposisi, maka mampu pula berbahasa Indonesia yang baik dan benar. Hal inilah yang harus ditanamkan pada anak didik (siswa). Siswa diharapkan mampu berbahasa Indonesia yang baik dan benar dalam berbagai ragam tulisan, termasuk menulis karangan eksposisi.

\section{Kemampuan} tersebut merupakan salah satu tujuan dan tuntutan dalam Kurikulum Tingkat Satuan Pendidikan Tahun 2006, khususnya pada tingkat pendidikan SMP kelas VIII. Tujuan yang dimaksud, yaitu mengungkapkan informasi dalam berbagai bentuk paragraf (naratif, deskriptif, ekspositif) dengan tujuan khusus, yaitu menulis hasil observasi dalam bentuk paragraf deskriptif.

Berdasarkan uraian tersebut maka pembelajaran menulis karangan eksposisi sangat perlu diajarkan di sekolah. Akan tetapi, kenyataan menunjukkan bahwa kompetensi siswa menulis karangan eksposisi sampai saat ini tergolong rendah. Hal ini diketahui berdasarkan penelitian terdahulu yang menyimpulkan bahwa kompetensi siswa menulis karangan eksposisi masih kurang. Selain itu, siswa kurang berminat pada kegiatan menulis karangan eksposisi. Siswa lebih menyukai berkomunikasi secara lisan karena berkomunikasi secara lisan lebih mudah dibandingkan dengan berkomunikasi secara tertulis. Hal inilah yang menyebabkan siswa tidak mampu melakukan kegiatan menulis karangan eksposisi sebagai perwujudan bentuk komunikasi tertulis.

Fenomena lain di kelas VIII-6 SMP Negeri 12 Makassar berdasarkan observasi awal penulis menunjukkan 
bahwa pembelajaran menulis karangan eksposisi dilaksanakan dengan berorientasi pada hasil dan mengabaikan proses. Proses menulis ini menyebabkan siswa kurang kreatif dalam menciptakan ide, lambat dalam proses menulis, siswa sulit menggambarkan suatu objek, dan sebagainya. Dengan demikian, pembelajaran kurang bermakna dan kurang berkesan bagi siswa.

Kendala tersebut menyebabkan kompetensi siswa menulis karangan eksposisi sampai saat ini tergolong rendah. Hal ini diketahui berdasarkan hasil pengamatan di lapangan, khususnya di kelas VIII-6 yang menunjukkan bahwa siswa tidak mampu menulis karangan eksposisi dengan baik yang disebabkan oleh berbagai kendala, seperti sulit menciptakan judul, kesulitan mengembangkan ide, serta isi karangan tidak mencerminkan karangan eksposisi. Hasil pembelajaran menulis karangan eksposisi tahun terakhir di kelas VIII6, yaitu tahun 2011 hanya mencapai rata-rata 65 . Demikian halnya dengan nilai ketuntasan pembelajaran menulis karangan eksposisi masih di bawah standar, yakni berkisar pada $68 \%$. Padahal, dalam KTSP tahun (2006) dinyatakan bahwa nilai ketuntasan siswa harus di atas 70 dan persentase ketuntasan minimal 85\%.

Salah satu strategi yang dapat digunakan untuk mengatasi problematik pembelajaran menulis karangan eksposisi tersebut, yaitu menerapkan strategi yang menarik dan sesuai dengan karakter dan minat belajar siswa. Strategi yang dimaksud, yaitu picture and picture (gambar bersusun). Picture and picture adalah suatu strategi belajar yang menggunakan gambar dan dipasangkan/diurutkan menjadi urutan logis. Sangatlah efektif pembelajaran menulis karangan eksposisi dengan bantuan gambar secara bersusun karena menuntun siswa untuk berkreasi sesuai dengan tuntunan dalam gambar. Melalui gambar tersebut siswa merasa mudah mengembangkan idenya ke dalam bentuk karangan eksposisi karena telah tampak gerakan-gerakan tak langsung 
suatu objek sehingga siswa tinggal memformulasikan objek itu dalam kalimat.

\section{Kajian Teori}

\section{Keterampilan Menulis}

Menulis merupakan suatu keterampilan berbahasa dapat diartikan sebagai kemampuan seseorang untuk mengukapkan pikiran dan idenya kepada yang lain atau kepada dirinya sendiri melalui bahasa tulis.

$$
\text { Lado (dalam Tarigan, 1993:21) }
$$

mengemukakan bahwa menulis ialah menurunkan atau melukiskan lambang-lambang grafik yang menggambarkan suatu bahasa yang dipahami oleh seorang, sehingga orang lain dapat membaca lambang grafik tersebut kalau mereka memahami bahasa dan gambaran grafik itu. Gambaran atau lukisan mungkin dapat menyampaikan makna-makna, tetapi tidak menggambarkan ketentuanketentuan bahasa. Menulis merupakan representasi (penulis) bagian dari ketentuan-ketentuan ekspresi bahasa,
Hal ini merupakan perbedaan utama antara lukisan dun tulisan.

$$
\text { Menurut Natia }
$$

karangan adalah suatu proses kegiatan pikiran seseorang yang hendak mengungkapkan buah pikiran dan perasaannya kepada orang lain atau kepada dirinya sendiri dalam bentuk tulisan. Mengarang meliputi bagaimana cara penulis melahirkan isi kesadarannya (gagasan, perasaan dan ungkapan efektif dan intensif, bagaimana cara menyusun dan menarik perhatian, dan lain-lain (Alwi, dkk. Eds., 2005: 45). Selanjutnya, The (1992:17) mengatakan mengarang adalah keseluruhan rangkaian kegiatan seseorang mengungkapkan gagasan dan penyampaian melalui bahasa tulis kepada pembaca.

Berdasarkan uraian di atas
dapat disimpulkan bahwa menulis
adalah keseluruhan rangkaian kegiatan
seseorang mengungkapkan buah
pikiran dan perasaannya kepada orang
lain atau kepada dirinya sendiri
melalui bahasa tulis.
Eksposisi atau pemaparan
adalah salah satu bentuk tulisan atau


retorika yang berusaha untuk menerangkan atau menguraikan suatu pokok pikiran yang dapat memperluas pandangan atau pengetahuan seseorang yang membaca uralan tersebut. Eksposisi merupakan bentuk retorika yang sering dipergunakan dalam menyampaikan uraian-uraian ilmiah populer dan uraian-uraian ilmiah lainnya yang tidak berusaha mempengaruhi pendapat orang lain. Makalah-makalah ilmiah populer dalam harian, mingguan, dan majalah bulanan biasanya disajikan dalam bentuk eksposisi. Setiap pembaca boleh menolak dan boleh menerima apa yang dikemukakan penulis tadi. Tetapi sekurang-kurangnya pembaca sudah tahu bahwa ada yang berpendapat atau berpendirian demikian (Ambo Enre dkk., 1985: 92).

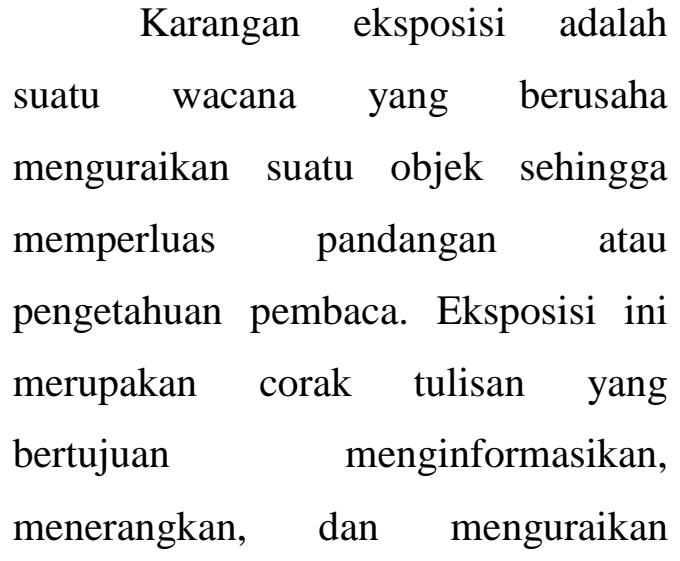

sesuatu gagasan (Alwi, 2001: 44). Selanjutnya, Keraf (2001: 7) mengatakan bahwa eksposisi adalah suatu bentuk wacana yang berusaha menguraikan suatu objek sehingga dapat memperluas pandangan atau pengetahuan pembaca. Sementara itu, Finosa (2004: 24) mengatakan bahwa dalam karangan eksposisi, masalah yang dikomunikasikan terutama adalah pemberitahuan atau informasi. Hasil karangan eksposisi yang berupa informasi dipaparkan dengan tujuan memperluas atau pengetahuan pembaca.

Eksposisi bertujuan menjelaskan, menerangka sesuatu, atau memberikan informasi sejelasjelasnya (Nursisto, 2000: 41). Ciri-ciri karangan eksposisi adalah (a) berisi penjelasan atau informasi; (b) menggunakan contoh, fakta, gambar, dan angka-angka; serta (c) akhir karangan berupa penegasan.

Eksposisi atau paparan ialah jenis karya tulis yang berusaha menjelaskan pokok pikiran yang dapat memperluas pengetahuan membaca. Eksposisi ditulis untuk menjawab : 
bagaimana ia berlangsung? Bagaimana caranya? Apakah itu?

\section{METODE PENELITIAN}

Penelitian ini termasuk penelitian tindakan kelas (Class room action research) yang bertujuan meningkatkan kemampuan menulis karangan eksposisi dengan menggunakan strategi picture and picture siswa kelas VIII-6 SMP Negeri 12 Makassar. Penelitian tindakan kelas dilaksanakan dalam bentuk kegiatan bersiklus yang terdiri atas empat tahap yaitu perencanaan, pelaksanaan tindakan, observasi, dan refleksi. Penelitian ini dilaksanakan di kelas VIII-6 SMP Negeri 12 Makassar yang berjumlah 26 orang, terdiri atas 13 orang laki-laki dan 13 orang perempuan. Penelitian ini dilaksanakan pada semester ganjil 2011/2012. Instrumen penelitian ini adalah observasi dan tes. Teknik pengumpulan data penelitian ini dilakukan dengan mengobservasi dan menguji kemampuan siswa. Observasi dilakukan pada saat peneliti mengamati latar kelas dan suasana berlangsungnya pembelajaran. Setiap siklus dilakukan bersama-sama dengan guru secara kolaboratif. Data yang telah terkumpul dianalisis dengan menggunakan teknik analisis kuantitatif dan kualitatif.

\section{PEMBAHASAN}

Pelaksanaan penerapan strategi picture and picture dapat meningkatkan keterampilan menulis karangan eksposisi siswa kelas VIII-6 SMP Negeri 12 Makassar. Dapat dinyatakan bahwa siswa yang mengikuti proses belajar mengajar selama penelitian berlangsung adalah 26 orang. Hal ini berarti bahwa semua siswa hadir pada pelaksanaan siklus I dan II.

\section{Siklus I}

Hasil analisis kualitatif dan kuantitatif menunjukkan bahwa pada dasarnya palaksanaan pembelajaran menyusun karangan eksposisi dengan menggunakan strategi picture and picture dan media gambar memberikan perubahan proses dan hasil belajar, 
yaitu terjadi peningkatan motivasi belajar (dari kurang aktif dan kurang termotivasi siklus I) menjadi aktif dan termotivasi pada siklus II. Demikian halnya dengan hasil belajar dari siklus I ke siklus II mengalami peningkatan yang sangat signifikan.

Berdasarkan hasil observasi siswa pada siklus I diketahui bahwa pembelajaran menyusun karangan eksposisi melalui strategi picture and picture dan media gambar dapat mengaktifkan siswa, walaupun peningkatannya masih kurang. Hal ini terlihat pada tabel persentase kegiatan dan keaktifan siswa yang menjawab pertanyaan guru; siswa yang mengajukan diri mengerjakan soal di papan tulis dan peningkatan ini masih tergolong kurang. Hal ini sangat dipengaruhi oleh rasa percaya diri siswa yang kurang untuk tampil di depan kelas. Selain itu, siswa merasa bingung dalam pembelajaran menyusun karangan dengan menggunakan strategi picture and picture dan media gambar. Melihat keadaan demikian guru berusaha membangun rasa percaya diri siswa dengan jalan memotivasi melalui pemberian penguatan dan menuntun siswa selama pembelajaran.

Pembelajaran menyusun karangan siklus I melalui strategi picture and picture dan media gambar tampak pada aspek siswa dan guru. Aspek siswa, yaitu: (1) siswa kurang memperhatikan gambar; (2) siswa kurang memperhatikan topik yang akan disusun dan ditulis; (3) siswa kurang aktif dalam kegiatan belajar mengajar; (4) siswa kurang memperhatikan gambar yang ditampilkan; (5) siswa kurang mampu menjawab pertanyaan tentang gambar yang ditampilkan; (6) siswa kurang menyimak penjelasan tiap-tiap gambar yang ditampilkan; (7) siswa kurang memperhatikan contoh cara menyusun karangan yang tepat menurut gambar; (8) siswa kurang mampu menyusun karangan yang tepat berdasarkan urutan gambar; (9) siswa kurang mampu menulis kalimat berdasarkan gambar; dan (10) siswa memeriksakan pekerjaannya dengan banyak kesalahan. 
Dari aspek guru, hal yang ditemukan, yaitu: (1) guru belum mengidentifikasi masalah siswa secara menyeluruh; (2) guru kurang membantu dan mengarahkan siswa menyelesaikan masalah; (3) guru kurang memberikan motivasi belajar siswa; (4) guru kurang memberikan gambaran bahwa siswa yang pintar menulis akan pintar pula berkomunikasi; (5) guru kurang menerapkan pujian/penguatan; (6) guru kurang memberikan hadiah bagi siswa yang berprestasi; (7) guru kurang menerapkan hukuman bagi siswa yang tidak memperhatikan pelajaran; (8) media yang digunakan adalah strategi picture and picture dan media gambar namun guru kurang menuntun siswa dalam menulis dengan media gambar terutama dalam mengidentifikasi karakteristik gambar yang dijadikan bahan menulis karangan; dan (9) guru tidak menuntun siswa secara terstruktur dalam menulis karangan, mulai proses observasi media gambar, pemahaman isi, cerita, diksi, ketepatan kalimat, ejaan, dan kerapian.
Temuan tersebut merupakan masalah dalam pembelajaran menyusun karangan eksposisi dengan menggunakan media gambar. Temuan tersebut pada dasarnya merupakan masalah.

Kemampuan menulis karangan eksposisi dengan menggunakan strategi picture and picture pada siklus I yang berkategori sedang. Hal ini terlihat dari persentase untuk kategori sangat tinggi dan tinggi yang sangat kurang. Ketuntasan kemampuan menulis karangan eksposisi dengan menggunakan strategi picture and picture pada siklus I sebesar 34,61\% atau 9 siswa berada dalam kategori tuntas dan sebanyak 17 orang atau $63,39 \%$ berada dalam kategori tidak tuntas. Hal ini berarti bahwa masih perlu perbaikan pada siklus berikutnya.

\section{b. Siklus II}

Kurangnya yang tuntas pada siklus I dapat ditingkatkan dengan mengoptimalkan pembelajaran pada siklus II. Hal-hal yang dilakukan, yaitu: (1) guru mengidentifikasi 
masalah siswa secara menyeluruh; (2) guru membantu dan mengarahkan siswa menyelesaikan masalah; (3) guru memberikan motivasi belajar siswa; (4) guru memberikan gambaran bahwa siswa yang pintar menulis akan pintar pula berkomunikasi; (5) guru menerapkan pujian/penguatan; (6) guru memberikan hadiah bagi siswa yang berprestasi; (7) guru menerapkan hukuman bagi siswa yang tidak memperhatikan pelajaran; (8) media yang digunakan adalah media gambar dan guru menuntun siswa dalam menulis dengan media gambar terutama dalam mengidentifikasi karakteristik gambar yang dijadikan bahan menulis kalimat; dan (9) guru menuntun siswa secara terstruktur dalam menulis, mulai proses observasi media gambar, diksi, ketepatan kalimat, ejaan, dan kerapian.

Pelaksanaan penerapan media gambar dalam meningkatkan kemampuan menulis karangan eksposisi terdiri atas enam tahap, yaitu (1) Tahap penanaman konsep. Pada tahap ini, kegiatan guru dan siswa adalah (a) menjelaskan materi pembelajaran, (b) membentuk kelompok, (c) siswa membaca materi dan menjelaskan pengertian menulis, mengarang, kerangka karangan, dan gambar. (2) Tahap menampilkan gambar. Kegiatan guru dan siswa adalah (a) guru memberikan kesempatan kepada siswa memperhatikan gambar, (b) guru mengarahkan siswa pada topik yang akan disusun dan ditulis, (c) guru mengaktifkan skemata siswa yang berhubungan dengan gambar. (3) Tahap menjelaskan gambar. Kegiatan guru dan siswa adalah (a) guru mengarahkan perhatian siswa terhadap gambar yang ditampilkan, (b) guru mengajukan pertanyaan kepada siswa tentang gambar yang ditampilkan, (c) siswa menjelaskan gambar yang ditampilkan. (4) Tahap menyusun kalimat. Kegiatan guru dan siswa adalah (a) guru memberikan contoh cara menyusun kalimat yang tepat menurut gambar, (b) guru memberikan kesempatan kepada siswa menyusun kalimat yang tepat berdasarkan gambar. (5) Tahap menyusun kerangka karangan. Kegiatan guru dan siswa 
adalah siswa menyusun kerangka karangan berdasarkan gambar dengan tuntunan guru. (6) Tahap pembahasan. Kegiatan guru dan siswa adalah (a) guru memeriksa pekerjaan siswa dan siswa melaporkan hasil pekerjaan.

Melalui langkah tersebut, ditemukan aktivitas siswa siklus II, yaitu: (1) perhatian siswa terhadap media gambar sangat baik; (2) perhatian siswa terhadap topik yang akan disusun dan ditulis sangat baik; (3) siswa sangat aktif dalam kegiatan belajar mengajar; (4) perhatian siswa terhadap gambar yang ditampilkan sangat baik; (5) kemampuan siswa menjawab pertanyaan tentang gambar yang ditampilkan sangat baik; (6) keaktifan siswa menyimak penjelasan tiap-tiap gambar yang ditampilkan sangat baik; (7) perhatian siswa terhadap contoh cara menyusun kalimat yang tepat menurut gambar sangat baik; (8) keaktifan siswa menyusun kalimat yang tepat berdasarkan urutan gambar sangat baik; (9) keaktifan siswa menyusun kalimat berdasarkan gambar sangat baik; dan (10) keaktifan siswa memeriksakan pekerjaannya sangat baik.

Secara khusus penilaian hasil tulisan siswa selama pembelajaran menulis karangan eksposisi pada siklus II dapat dipaparkan sebagai berikut. (1) Kesesuaian topik penulisan dengan tema telah mencapai ketuntasan belajar dengan kualifikasi sangat baik. (2) Kesesuaian susunan pertanyaan dan jawaban dengan pengembangan topik (dengan kata tanya: apa, mengapa, dan bagaimana) tercapai ketuntasan dengan kualifikasi sangat baik. (3) Kerangka tulisan menggambarkan penguraian topik tercapai ketuntasan belajar dengan kualifikasi sangat baik. (4) Penentuan judul sesuai dengan tema, topik, dan isi karangan tercapai ketuntasan belajar dengan kualifikasi sangat baik. (5) Keterincian pengembangan gagasan dengan penalaran telah mencapai ketuntasan belajar dengan kualifikasi sangat baik. (6) Ketepatan pengorganisasian gagasan dengan unsur kriteria paragraf yang baik (kelengkapan, keruntutan, keutuhan dan kepaduan) telah mencapai ketuntasan belajar dengan 
kualifikasi sangat baik. (7) Ketepatan penggunaan unsur wacana deskriptif mencapai ketuntasan belajar dengan kualifikasi sangat baik. (8) Ketepatan penggunaan unsur kebahasaan (tanda baca, ejaan, dan diksi) dalam tulisan tercapai ketuntasan belajar dengan kualifikasi sangat baik.

Berdasarkan temuan penilaian hasil tulisan yang dicapai oleh siswa selama pembelajaran menulis karangan eksposisi pada siklus II hampir semua siswa terteliti telah mencapai ketuntasan belajar. Walaupun, ada siswa yang mengalami sedikit hambatan pada dua aspek dalam pembelajaran menulis siklus II, yaitu pemenuhan unsur kriteria wacana eksposisi yang baik dan ketepatan pemakaian unsur mekanik kebahasaan. Hal tersebut, dapat ditempuh dengan konferensi kecil antar siswa dalam kelompok dengan bimbingan guru, maka hambatan dapat teratasi. Dengan demikian, hasil tulisan siswa pada siklus II telah menunjukkan peningkatan yang sangat signifikan.

Berdasarkan uraian tersebut, nilai hasil belajar menyusun karangan eksposisi meningkat. Hasil belajar pada siklus II (nilai rata-rata), yaitu 79,96. Nilai tertinggi adalah 96 dan nilai terendah adalah 62 . ketuntasan hasil belajar menulis karangan berdasarkan gambar pada siklus II sebesar $88,47 \%$ atau 23 siswa berada dalam kategori tuntas dan 3 siswa atau $11,53 \%$ berada dalam kategori tidak tuntas. Hal ini berarti bahwa ketuntasan siklus II memadai. Berdasarkan kriteria hasil belajar mengenai ketuntasan kelas, yaitu $\geq$ $85 \%$, data hasil penelitian pada siklus II ini sudah tuntas secara kelas karena yang tuntas mencapai $88,47 \%$ dari 26 orang siswa.

\section{SIMPULAN}

Berdasarkan hasil pembahasan, disimpulkan hasil penelitian ini, yaitu:

1. Perencanaan penerapan strategi picture and picture dalam meningkatkan keterampilan menulis karangan eksposisi siswa kelas VIII-6 SMP Negeri 12 Makassar disusun dengan menelaah kurikulum, mempelajari bahan yang 
diajarkan dari berbagai sumber, membuat rencana pembelajaran (RPP) untuk dua kali pertemuan, menyediakan sarana pendukung yang diperlukan (media gambar), membuat lembar observasi untuk keaktifan siswa pada saat proses belajar mengajar, serta menyusun soal sebagai alat evaluasi.

2. Pelaksanaan penerapan strategi picture and picture dalam meningkatkan keterampilan menulis karangan eksposisi siswa kelas VIII-6 SMP Negeri 12 Makassar dilaksanakan selama dua siklus. Setiap siklus terdiri atas tiga kali pertemuan dengan tahap sebagai berikut: tahap penanaman konsep, tahap menampilkan gambar, tahap menjelaskan gambar, tahap menyusun kalimat, tahap menyusun kerangka karangan, dan tahap pembahasan.

3. Hasil belajar pada siklus I dikategorikan tinggi, sedangkan pada siklus kedua meningkat menjadi kategori sangat tinggi. Dengan demikian, dapat disimpulkan bahwa strategi picture and picture meningkatkan keterampilan menulis karangan eksposisi siswa kelas VIII-6 SMP Negeri 12 Makassar. Hal ini tampak pada kemampuan siswa siklus satu dikategorikan sedang dan meningkat pada siklus kedua menjadi kategori tinggi.

\section{DAFTAR PUSTAKA}

Alwi, Hasan, dkk. (Eds.). 2005. Kamus Besar Bahasa Indonesia Edisi III. Jakarta: Balai Pustaka.

Alwi, Hasan. 2001. Paragraf. Jakarta: Pusat Bahasa.

Ambo Enre, Fachruddin dkk. 1985. Bahasa Indonesia. Ujung Pandang: Badan Penerbit IKIP Ujung Pandang.

Ambo Enre, Fachruddin. 1994. Dasardasar Keterampilan Menulis. Ujung Pandang: Badan Penerbit IKIP Ujung Pandang. 


\begin{tabular}{|c|c|c|}
\hline Darmadi, & $\begin{array}{lr}\quad \text { Kaswan. } & 1996 . \\
\text { Meningkatkan } & \\
\text { Kemampuan } & \text { Menulis. } \\
\text { Yogyakarta: } & \text { Andi } \\
\text { Opset. } & \end{array}$ & $\begin{array}{l}\text { Suprijono, Agus. 2009. Cooperative } \\
\text { Learning. Jakarta: } \\
\text { Pustaka Pelajar. }\end{array}$ \\
\hline Latuheru, & $\begin{array}{ll}\text { J.D., } 1993 . & \text { Media } \\
\text { Pembelajaran. } & \text { Ujung } \\
\text { Pandang: IKIP } & \text { Ujung }\end{array}$ & $\begin{array}{l}\text { Keterampilan } \\
\text { Berbahasa. Bandung: } \\
\text { Angkasa. }\end{array}$ \\
\hline Natia, & $\begin{array}{l}\text { I.K. } 1994 . \quad \text { Bimbingan } \\
\text { Mengarang. Surabaya: } \\
\text { Arkola. }\end{array}$ & 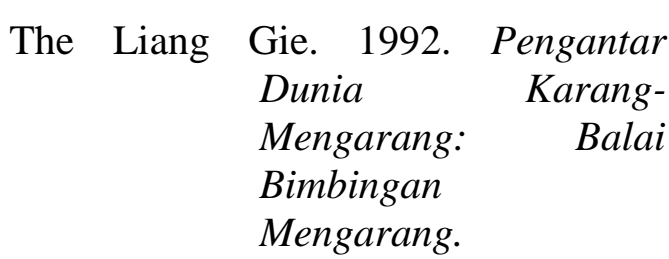 \\
\hline Nursisto. 2 & $\begin{array}{l}\text { 2000. Penuntun Mengarang. } \\
\text { Jakarta: Adi Cita. }\end{array}$ & Yogyakarta: Liberty. \\
\hline uwin, Jol & $\begin{array}{lr}\text { kaho dan Sutjarso } & \text { A.S., } 1996 . \\
\text { Baha } & \text { Indonesia. } \\
\text { Makassar: } & \text { FKIP } \\
\text { Unismuh. } & \end{array}$ & \\
\hline
\end{tabular}

